\title{
Innovation Dynamics of Socio-Technical Alignment in Community Energy Storage: The Cases of DrTen and Ecovat
}

\author{
Binod Prasad Koirala ${ }^{1,2, *}$, Ellen van Oost ${ }^{2}$ and Henny van der Windt ${ }^{3} \mathbb{C}$ \\ 1 Energy Transition Studies, TNO Energy Transition, 1043 NT Amsterdam, The Netherlands \\ 2 Department of Science, Technology and Policy Studies, University of Twente, \\ 7522 NB Enschede, The Netherlands; e.c.j.vanoost@utwente.nl \\ 3 Science and Society Group, Faculty of Science and Engineering, University of Groningen, \\ 9747 AG Groningen, The Netherlands; h.j.van.der.windt@rug.nl \\ * Correspondence: binod.koirala@tno.nl
}

Received: 29 April 2020; Accepted: 5 June 2020; Published: 9 June 2020

\begin{abstract}
With energy transition gaining momentum, energy storage technologies are increasingly spotlighted as they can effectively handle mismatches in supply and demand. The decreasing cost of distributed energy generation technologies and energy storage technologies as well as increasing demand for local flexibility is opening up new possibilities for the deployment of energy storage technologies in local energy communities. In this context, community energy storage has potential to better integrate energy supply and demand at the local level and can contribute towards accommodating the needs and expectations of citizens and local communities as well as future ecological needs. However, there are techno-economical and socio-institutional challenges of integrating energy storage technologies in the largely centralized present energy system, which demand socio-technical innovation. To gain insight into these challenges, this article studies the technical, demand and political articulations of new innovative local energy storage technologies based on an embedded case study approach. The innovation dynamics of two local energy storage innovations, the seasalt battery of DrTen ${ }^{\circledR}$ and the seasonal thermal storage Ecovat ${ }^{\circledR}$, are analysed. We adopt a co-shaping perspective for understanding innovation dynamics as a result of the socio-institutional dynamics of alignment of various actors, their articulations and the evolving network interactions. Community energy storage necessitates thus not only technical innovation but, simultaneously, social innovation for its successful adoption. We will assess these dynamics also from the responsible innovation framework that articulates various forms of social, environmental and public values. The socio-technical alignment of various actors, human as well as material, is central in building new socio-technical configurations in which the new storage technology, the community and embedded values are being developed.
\end{abstract}

Keywords: energy transition; community energy storage; responsible innovation; energy system integration; socio-technical innovation

\section{Introduction}

Currently, the energy system is at a crossroads and is going through rapid techno-economical and socio-institutional changes both at the central and the local level [1-5]. New distributed energy resources such as solar photovoltaics, wind and energy storage technologies are emerging in the energy landscape [6,7]. These changes demand the increased engagement of citizens and communities in the energy system [8-13]. Accordingly, there are new regulatory and governance changes such as new European clean energy for all packages, as well as new societal developments in the form of local 
energy initiatives [3,5,9,14-17]. The concept of Renewable Energy Communities (REC) and Citizen Energy Communities (CEC) were introduced in the European legislation by the 2018 recast of the European Renewable Energy Directive (RED II) and the 2019 recast of the Electricity Market Directive (EMD II), respectively $[18,19]$. These institutional transformations caused resulting techno-economic changes in the energy system which imply not only political and socio-economic issues in the energy system transformation, but also fundamental shifts in the way the energy system is organized and operated [2,20-22]. As innovation becomes more rapid and complex, uncertainty increases regarding the effectiveness of existing policies and regulations, as well as the permissibility of the innovations [23]. Moreover, there are serious challenges concerning their embedding in existing technological and societal frames and systems.

The transforming energy system has to be more adaptive, diverse and flexible to accomodate increasing temporal fluctuations in both supply and demand [5]. Supply fluctuations are growing with the increasing penetrations of intermittent solar and wind. Both energy demand as well as its fluctuation will rise due to the increasing electrification of different end-use sectors such as heating and transport. With higher intermittent generation through solar and wind as well as changing consumption patterns, the mismatch between supply and demand will only increase in future. Energy storage is seen as crucial for solving this mismatch, and thus is expected to gain an important place in a future sustainable energy system $[21,24,25]$.

Storage technologies of the future have many different shapes, scale, functions and politics. As trends and developments in energy storage technologies are fast-moving, no dominant community energy storage technology has cristallized to date. Neither is it clear how these innovations will possibly affect the energy system and society as a whole. Furthermore, advances in information technology and digitalization generate a wide variety of new applications and services for energy storage. The new opportunities and challenges created by these innovations are unclear. Currently, at least three approaches can be identified: storage close to production sites, for instance configurations of wind parks and hydrogen storage facilities, storage close to consumers, such as home and neighborhood battery systems, and in-between approaches, such as configurations of electricy and thermal storage by water or gas $[5,24]$.

In this study, we focus on analyzing local storage innovations close to (a community of) consumers, as we are interested in how energy innovations can empower local communities. Local communities simultaneously can be a breeding place for social and technological energy innovations [5,26-30]. New technologies, co-operations, markets and energy attitudes can develop, stimulating social, cultural and economic activities of the local communities. Various factors have been identified for these successes: cultural backgrounds, timely cooperation between local initiatives, technology developers and firms as well as support by the governments [31]. The innovation of windmills in Denmark and solar collectors in Austria is explained by the design of the technology, orchestrated learning processes between owner-user groups and firms, specific cultural traditions and governmental policy [32,33]. The skills and attitudes of the people involved in the initiatives and cooperation on different societal levels have also been noted as main factors [34,35].

Local energy initiatives can be seen as a specific innovative sector, characterized by its own social dynamics, values, technological preferences and learning processes. According to Seyfang et al. (2014), innovations by these types of initiatives differ from market-based innovations in several ways [36]. For these innovations, social and/or environmental needs are driving forces, which means that collective values such as locality, solidarity and sustainability outweigh efficiency and profit. The input of volunteers, grant funding and reciprocity are as least as important as business loans or commercial norms, and output in terms of greening society is at least as important as material economic results. In addition, cooperatives, and voluntary organisations are dominant organisational forms, and firms are rare. However, for these initiatives, connections to other energy actors, through intermediaries or networks, is crucial $[37,38]$. Thus, local communities are an interesting and relevant place to study energy innovation dynamics and the processes of socio-technical alignment, meaning giving and social 
learning which may constitute new innovative socio-technical configurations that may be one of the building blocks for the future energy transition.

Local communities, thus, are an interesting place to study the dynamics of energy storage innovations as the involved collective values often go beyond market values and include other social values like environmental, justice, fairness and privacy. We aim to study local energy storage innovations that allow for new roles and responsibilities for citizens, e.g., as energy prosumers or even prosumagers (combining production, storage and comsumption). This type of socio-technical innovation could grant local energy collectives more agency to realize their sustainability goals. The energy storage innovations themselves are not neutral and also embody values, have politics and exercise agency $[39,40]$. This paper will analyze two emerging local energy storage innovations that explicitly embody environmental and social values in their basic design, the seasalt battery of $\operatorname{DrTen}^{\circledR}$ and the thermal storage Ecovat ${ }^{\circledR}$, which, respectively, avoid toxic or scarce elements and minimize visual impact on the landscape. Both local storage innovations are on the verge of market introduction and still have to be implemented in and adapted to use situations. As such, these two innovations allows for gaining insights into the co-shaping dynamics during the early implementation processes that may lead to new innovative and socio-technical local energy configurations, that could potentially form an important element of the future energy system transition.

Our research is embedded in the recently developed innovation policy framework of Responsible Research and Innovation (RRI) for guiding technological innovations towards strengthening social and ecological welfare next to economic goals (For example, The Netherlands Research Organization (NWO) has developed the Responsible Innovation research programme (NWO-MVI). The programme identifies the ethical and societal aspects of technological innovations at an early stage so that these can be taken into account in the design process) [5,41]. This RRI perspective is described as "taking care of the future through collective stewardship of science and innovation in the present" [42]. RRI is not only a policy framework for innovation, but also a growing field of research. To date, energy innovations are underrepresented in the RRI literature [43]. Although no reasons for this are given, one could argue that many energy innovations today strive towards a more sustainable energy system and thus already have an environmental embedded normativity. Yet, energy innovations may raise new societal tensions (e.g., large windmills on land) or future unwanted impacts like shortages of rare materials (lithium), waste problems (old windmill wings) or new social problems like energy poverty, or new forms of social inequality as not everyone can afford energy innovations and benefit from them. Our study aims to contribute to insight into possible pathways and pitfalls for a responsible energy innovation dynamics through an empirical study of the development and implementation of two sustainable storage innovations in local energy communities.

We study the innovative potential of local energy initiatives in terms of energy storage technology adoption, social embeddedness and normativity through various forms of alignment with the innovative potential of emerging energy storage technologies, including their normative social, politcal and environmental dimensions. In our research, we will address the question of how to orchestrate socio-technical alignment issues in the implementation of innovative community energy storage technologies. We aim to gain insight into the local contextualized co-shaping dynamics of local energy storage innovation and the local network of involved actor groups.

The article is organized as follows. First of all, in Section 2, a conceptual research framework is provided. In Section 3, research design and methods are outlined. Section 4 presents the case studies of emerging responsible community energy storage innovations, DrTen ${ }^{\circledR}$ and Ecovat ${ }^{\circledR}$. Finally, Section 5 provides a conclusion and discussion on socio-technical alignment dynamics in the implementation of responsible innovations in community energy storage.

\section{Conceptual Research Framework}

In this section, we will elaborate the conceptual research framework. First, we will elaborate on how we use and define the concept of community energy storage. Second, we elaborate on our social 
constructive and co-evoluationary perspective on technological development as recently developed in science and technology studies (STS).

We refer to community energy storage as a subset of the overarching concept of "community energy" [3,8,16,20,44-62]. The exisiting energy communities may provide fruitful ground for the adoption, development and implemention of community energy storage [5]. In essence, the difference is mainly technological but there may also be minor socio-institutional differences. The storage technology enables local communities to have higher control of their energy systems. At the same time, the interactions with institutional actors as well as business models are slightly different to community energy.

Several definitions of community energy storage are available $[5,21,28,30,63,64]$. Robert and Sandberg (2011) see community energy storage as an intermediate solution between residential and utility-scale energy storage, whereas Parra et al. (2017) suggest that community energy storage brings benefits both consumers and system operators [21,65]. Koirala et. al. (2018a) define community energy storage as "an energy storage system with community ownership and governance for generating collective socio-economic benefits such as higher penetration and self-consumption of renewables, reduced dependence on fossil fuels, reduced energy bills, revenue generation through multiple energy services as well as higher social cohesion and local economy" [5]. To the knowledge of the authors, the research on community energy storage systems to date has a main focus on techno-economic aspects and limited attention towards societal, institutional and environmental aspects (notable exemptions are $[5,13,21]$ ) This article analyzes community energy storage from a socio-technical perspective. This approach allows to investigate interactions and dynamics between different actors and components of community energy storage. The focus is on the socio-technical alignment of community energy storage systems as well as their transformative capacity.

Pragmatic theories such as domestication theory, social practice theory and actor-network theory offer research tools to study socio-technical innovation dynamics [38,66-69]. An innovation is seen as an evolving socio-technical actor network with various material and societal actors and relations [66]. The actor network is a product of successful alignments of material as well as social and regulatory actors [66,69]. Jalas et. al. (2017) as well as van der Waal et al. (2020) highlight that experimentation opens up possibilities for participation for a wide range of actors [10,70]. Ryghaug and Toftaker (2014) combined social practice theory and a theory of domestication to study different dimensions of electric vehicle introduction in Norway [71]. From the energy transition perspective, frameworks such as technological innovation systems, multi-level perspectives as well as strategic niche management are relevant [72-75].

This research builds on these exisiting theories and frameworks and goes beyond them as it aims to stimulate social learning to improve the alignment and coordination of social and technological innovations and offers a unique opportunity to engage in and learn from reflexive social learning in aligning technical, demand and cultural articulation as a form of responsible innovation in the sustainable local energy storage technologies. We positioned our research as contributing to the innovation policy framework of Responsible Innovation. (RRI). RRI is not the conceptual framework but it does help in structuring the normative goals underlying this research.

This approach aims to stimulate "research and innovation outcomes aimed at the "grand challenges" of our time, for which they share responsibility. Research and innovation processes need to become more responsive and adaptive to these grand challenges. This implies, among others, the introduction of broader foresight and impact assessments for new technologies, beyond their anticipated market-benefits and risks" [76]. The RRI approach distinguishes four dimensions to guide the innovation process: anticipation, reflection, deliberation and responsivity [41]. Anticipation aims to gain insight in possible future societal impacts in an early phase of the innovation development. Reflection highligths and discusses social, ethical and environmental aspects of the anticipated impacts. Deliberation refers to involving relevant actor groups in the innovation process by highlighting their perspective in the challenges and uses of the new technology. Last, but not least, responsivity aims 
to feed back the insights and analyse of the three other dimensions into the ongoing development, implementation and societal embedding of the innovation. RRI thus broadens the technology design by including social, ethical, and environmental aspects and involving a variety of stakeholder groups [77]. However, there are also some critiques of RRI, one of the main ones being the limited availabily of indicators to measure the effects of RRI and important innovation barriers to including RRI values [78].

In each of these four dimensions, different forms of socio-technical linkages are created. When technologies are designed, assumptions are made regarding users, regulations, available infrastructures and responsibilities between various relevant stakeholders $[39,77]$. The notion of scripts links technological design choices (technological articulation) to expectations about users (demand articulation) and other stakeholders and regulations (political articulation). The technology developers, users, governments and other actors have their own set of assumptions and expectations. Moreover, it is important to allow the early and regular confrontation and exchange of these assumptions and expectations [77,79]. Devine-Wright et.al. (2017) studied the social acceptance of energy storage, combining market, socio-political, community and environmental aspects [69]. Energy storage is accepted or rejected in different ways in different geographical and societal contexts. Thus, it is important to consider the roles of different actors, their values, needs, expectations and interactions, as well as the materialization of technologies and their societal embedding in different contexts.

Figure 1 illustrates the way technological and societal elements are interwoven in complex socio-technical systems such as community energy storage [45,80-82]. These elements develop in co-evolutionary dynamical processes. Various societal stakeholders develop new routines and institutions embedding the new technologies by anticipation, reflexivity, deliberation and learning $[41,83]$.

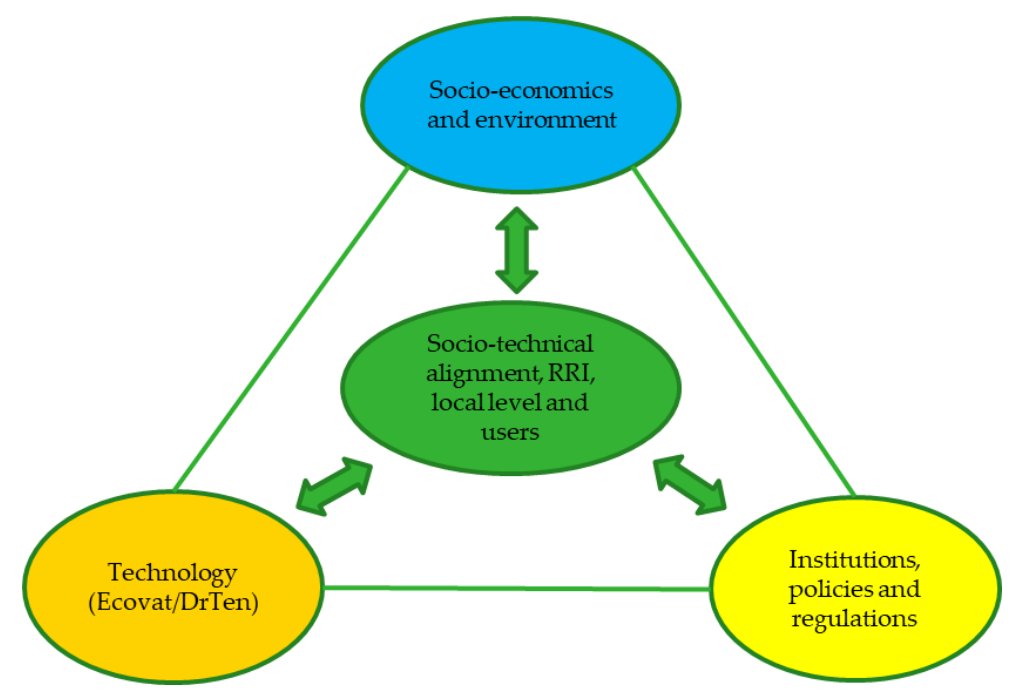

Figure 1. Research framework.

Socio-technical alignment may be seen as a process in which responsible innovation is achieved through identifying imperatives and anticipating incompatibilities in social and technical innovation and taking measures to counteract unwanted effects. Community energy storage technology also needs to overcome path dependency and the socio-technical lock-in of existing energy systems and should be related to various dimensions of society and its demands such as regulatory frames, already esisting technologies, organizations, environmental requirements and psychological issues of acceptibility $[81,84]$. Socio-technical alignment is central to overcoming these lock-ins and problems of acceptability.

In the next section, we will address how we studied the socio-technical alignment processes in the dynamics of community energy storage innovations by describing the development of two new technologies and by analyzing how they tried to include various values and needs, in particular 
citizens' involvement and environmental consideration, and to align both new storage technologies to existing technological and institutional configurations.

\section{Research Design and Methods}

The explorative, process-oriented research question of our study fits a qualitative approach based on a in-depth case studies [85]. The qualitative approach enables a detailed analysis of all actors and their positions and roles and the alignment dynamics. The selection of the two emerging Dutch storage innovation cases, Ecovat and DrTen, is based on sustainable, responsible design features, the high societal expectations and the developmental phase-a working prototype phase, with the intention to grow in coming years towards market introduction. The innovation was still open to accomocodate technological, social and regulatory articulations (responsiveness). The two cases are complementary in the sense that DrTen batteries focus on day/night electricity storage whereas Ecovat allows for thermal seasonal storage. These two cases allow for qualitative insight into a broad spectrum of involved actors and socio-technical alignment processes.

As community energy storage is at the early stage in the development process, conceptual tools from technology dynamics such as social actor analysis, dynamics of technological promises and expectations, script analysis and niche dynamics are applied to analyze socio-technical alignment processes of the community energy storage [86]. As an empirical source, we apply embedded case studies, based on interviews, participatory observation and document analysis. In particular, the development and initial adoption of two emerging innovative energy storage technologies in The Netherlands, Ecovat ${ }^{\circledR}$ and DrTen ${ }^{\circledR}$ has been followed $[87,88]$. For each storage innovation, we followed for a longer period two use-cases in two Dutch villages, Heeten (DrTen) and Wageningen Benedenbuurt (Ecovat), where the innovator-entrepreneurs collaborate with local communities, citizens, energy system actors and local government. These local use-cases offer a context in which different actors, both incumbent energy system actors as well as new energy actors, work together for a sustainable and decentralized energy future including an innovative community energy storage technology [89,90].

The data collection was carried out between November 2016 and April 2020. The embedded-case of Benedenbuurt was followed from November 2016 to April 2020, whereas the embedded-case of Gridflex Heeten was followed from March 2017 to April 2020. In the case of Benedenbuurt, we observed and participated in all project meetings in the period 2017-2018 and in three local initiative meetings. In addition, we interviewed key actors of the cooperative, the project team and the municipality. In the case of Gridflex Heeten, we attended various project meetings as well as the three information meetings for the participating residents. For the Benedenbuurt case, we collected several documents, which include the minutes of the local initiatives, feasibility studies, webpages and news articles, whereas for the gridflex Heeten we collected several documents including project proposal, flyers and webpages. For data on the technological and organizational development, we held interviews with technical sales manager of ECOVAT, marketing director of DrTen and initiators of both initiatives. We also collected and studied academic publications and other documents: two journal publications [91,92], three conference papers $[22,93,94]$, several expert reports, two patents $[95,96]$, several presentations, two master-theses [97,98] and one PhD thesis [99] related to ECOVAT and, for Dr.Ten batteries, three journal publications $[5,100,101]$, three conference papers $[22,102,103]$, several presentations and one PhD thesis [104].

The analysis of the collected data was not processed digitally, nor coded, but used to heuristically construct a qualitative understanding of the innovation dynamics, by focusing on identifying the relevant actor groups, their changing definitions, articulated meanings, agenda and process roles as well as crucial successful and failed socio-material alignments and re-alignments.

\section{Emerging Energy Storage Technologies: The Cases of DrTen ${ }^{\circledR}$ and Ecovat ${ }^{\circledR}$}

Current energy storage have several issues such as high costs, limited capacity and life time, use of rare earth or polluting materials, geographical dependency (e.g., pumped hydro and compressed 
air) and safety issues [105-107]. Sustainable, cheap and reliable energy storage is still a challenge [107]. In this context, two promising community energy storage innovations are emerging: DrTen ${ }^{\circledR}$ for short-term electrical energy storage and Ecovat ${ }^{\circledR}$ for seasonal thermal energy storage $[87,88]$. The DrTen ${ }^{\circledR}$ seasalt battery promises a sustainable, clean, and relatively cheap storage of electricity and can be applied at the level of households and communities. Seasonal themal storage Ecovat ${ }^{\circledR}$ stores heat in the summer, and this can be retrieved in winter. This storage system functions at the level of neighborhoods.

In this section, we will describe and analyse the socio-technical alignment dynamics of these two community energy storage innovations. Section 4.1 provides a more elaborate description of the case technologies and the evolving companies. In Section 4.2, we give an overview of the innovation dynamics summarized in a timeline overview. Section 4.3 describes the relevant actors and stakeholders and the way they contributed to the storage innovation as well as their mutual relations. Section 4.4 provides a more detailed analysis of a use case, a pilot that intended to implement the storage innovation. In Section 4.5, socio-technical alignment dynamics and strategies are elaborated.

\subsection{Key Characteristics}

Ecovat ${ }^{\circledR}$ is developed as reliable and affordable solution for solving the seasonal energy gap in (solar) renewables. As illustrated in Figure 2, Ecovat ${ }^{\circledR}$ is a large seasonal thermal storage with a smart control software. The physcial system of Ecovat ${ }^{\circledR}$ consists of large subteraranean buffer tank, heat exchangers, energy management systems, district heating networks and communication networks. Based on weather forcecast, actual electricity market prices and anticipated heat and electricity demand, the Ecovat ${ }^{\circledR}$ software can optimally operate the system. Thermal energy is stored as hot water in a large subterranean buffer tank. Test results show energy losses of less than $10 \%$ over six months [88]. The heat sources can be renewables (solar thermal) and geo-thermal as well as waste heat and electricity. The electricity should preferably come from renewable sources like solar or wind. This could also increase the rate of self-consumption of locally generated renewable electricity in single- or multi-apartment buildings as well as neighbourhoods [108]. It also has the potential to provide a local balance between supply and demand and provide $100 \%$ renewable heating and cooling. The subterranean buffer tank does not impact landscapes and is almost maintenance-free, as the system has no moving parts. The expected life expetancy for an Ecovat ${ }^{\circledR}$ system is 50 years. Through smart integrated infrastrucutes for heat and electricity, it has potential economic value propositions such as peak shaving of heating networks, congestion management, balancing of the electricity network, increased self-consumption of local generation, avoided grid-reinforcement costs due to the electrification of the residential heating sector, better utilization of waste heat, reduced energy prices, maximum use of renewables and minimum environmental impacts.

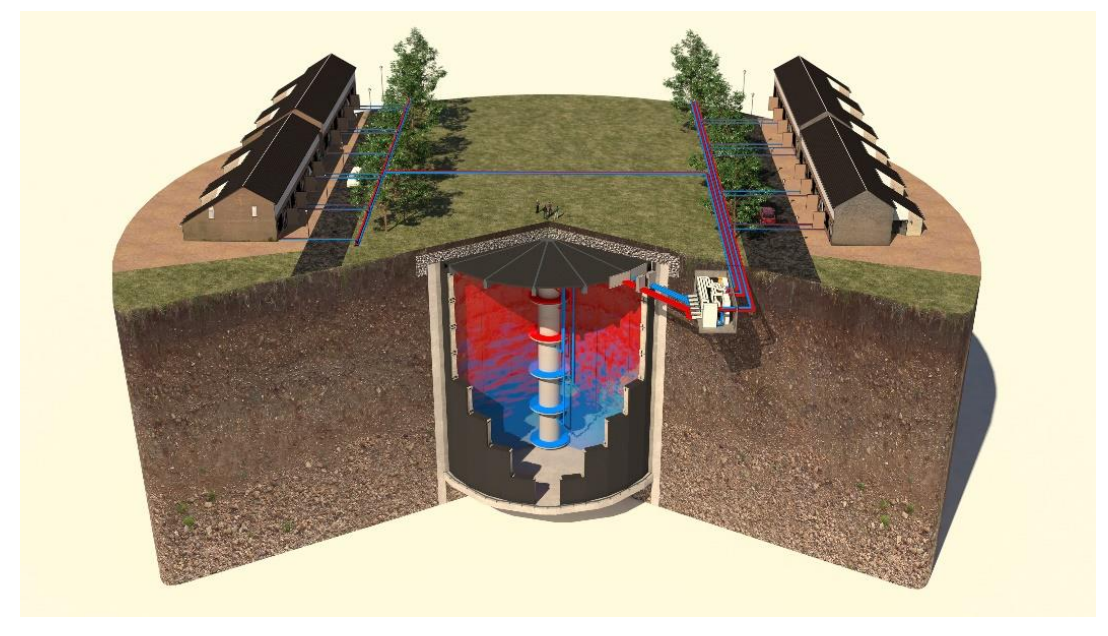

Figure 2. Ecovat ${ }^{\circledR}$ as large subterranean buffer tank. 
DrTen ${ }^{\circledR}$ provides safe, clean and affordable energy storage solutions. DrTen ${ }^{\circledR}$ seasalt batteries have seasalt as the main salt in the electrolyte and carbon electrodes. Currently, it has reached an energy density of about $35 \mathrm{Wh} / \mathrm{kg}$, comparable to about $20 \mathrm{Wh} / \mathrm{kg}$ for a lead acid battery with largest market share worldwide [87]. As materials used in seasalt batteries are green and low-costs, the prices are expected to be lower than existing batteries upon mass production. The battery is now in pilot production. It can be deep-discharged and charging and discharing cycles of more than 64000 have been recorded. To make it affordable, the batteries were originally housed in simple plastic cups, rainwater pipes followed by more professional boxes with pouch cells, also becoming more professional with some inspiration from green food packages andli-ion batteries. With materials still coming from China, Israel, Germany, the Netherlands and the US, cell-manufacturing has been relocated to Israel while the batteries are still being assembled manually to systems in the Netherlands. A future production lines are foreseen to be automated, with one cell per 5-20 seconds, leading to about 7 MWh per year. Currently, DrTen ${ }^{\circledR}$ batteries are being tested in several local energy pilots, such as gridflex Heeten [89] and Israel, scaling up materials and production with more massive implementation.

\subsection{Key Processes in Innovation Dynamics}

At around 2013, both technologies started in small firms, both specialized in sustainable technology, but had a larger portfolio. Ecovat ${ }^{\circledR}$ was founded by Aris de Groot, a successful architect and designer in sustainable buildings. DrTen ${ }^{\circledR}$ was owned by chemical technologist Marnix ten Kortenaar, who had worked at Delft University of Technology and a large chemical company. The initial idea for DrTen ${ }^{\circledR}$ batteries originated during his visit to Africa, based on fundamental research he has done in 1994 at Delft University of Technology, followed by various lab scale prototypes development between 2008 - 2013 and first simple prototype in 2014. Both took initiatives to develop their technologies, together with the technical universities of Delft and Twente and universities of applied sciences Avans and Hanze, involving Master and PhD students. In addition, they started pre-engineering or pilot projects together with municipalities, governmental science and technology funders, local stakeholders and grid operators. Because many of these parties were looking for innovative, sustainable and environmental friendly technologies which could be applied at local levels, both companies were attractive to cooperate with.

Below, we will describe the main activites of DrTen ${ }^{\circledR}$ and Ecovat ${ }^{\circledR}$ between 2013-2019. During 2013-2019, both innovations participated in and won several innovation prize contests. DrTen ${ }^{\circledR}$ received the prestigious Terlouw innovation prize in 2013, two Blauw tulp accenture innovation award in 2014, was seen as the most sustainable and innovative SME in the Netherlands (Squarewise) and belonged to the top 100 innovations in the Netherlands (RTL Z) in 2015. In addition, DrTen became successful in joining events and projects, such as pitches during Yes Delft (2015), a Turkish innovation week (2015) and the so-called Kenniskring smart energy of Innovation Centre Green Economy Noord-Veluwe (IGEV) (2016). The German magazine Bizz energy selected ECOVAT as innovation of the month (2015), it received the innovation award for sustainable energy from DSO Stedin and leading Dutch environmental organization Natuur and Milieu (2016), and it won the FLEXCON energy startup challenge (2017) and Enpuls flex energy gap challenge (2018). In 2019, Ecovat was included in the list of mission innovations, a global initiative to accelerate clean energy innovation [109].

In both cases, the focus has been not only on technology development but also on aligning the innovation with societal needs and requirements. DrTen started five pilot projects in the Dutch provinces of Zeeland, Gelderland, Groningen and Overijssel, while Ecovat started seven pre-engineering feasibility studies or pilots in the Dutch provinces of Zuid-Holland, Limburg, Noord-Brabant, Groningen and Gelderland and one in Germany. Most of these projects were co-financed by public funders, such as the EU and national funds for innovation, regional development or energy transition. In 2016, Dr. Ten joined a relatively large, publicly funded research consortium, concerning a pilot project on smart microgrids and local energy markets, a collaboration of academia, one of the largest DSOs (Enexis), 
a local energy cooperation, an ICT company and Buurkracht, an organization which specialized in citizen engagement in local energy projects, called Gridflex Heeten (this pilot project will serve a embedded use case, see Section 4.4). In various other subsidized energy projects, DrTen was welcomed as a storage technology partner, such as an INTERREG program, funded by the EU, Dutch ministry of economics and climate, North Rhein Westphalia ministry of economics, innovation, digitalization and energy and several Dutch provinces, the Northern Climate Summit in the province of Groningen to develop pilots, and COOBRAA/AVANS projects in the cities of Breda and Tilburg, for the development of sustainable concepts such as the "neighborhood battery' and an "autarkic (tiny) house" [110]. Although a marketable version of the battery still remained to be created, the sea salt battery of DrTen kept invoking the genuine interest of various governmental actors and other societal parties. For instance, in 2019 the province of Groningen asked DrTen to start pilots in this province, and in the province of Gelderland, DrTen won the Veluwe innovation prize for its battery, as a promising concept for sustainable, self-supporting urban smart grids.

The development of the ECOVAT ${ }^{\circledR}$ seasonal warm and cold storage system showed various similarities. In 2014, during the construction of the demo, Dutch innovation programs TKI and REAP subsidized the company, followed by subsidies from the Dutch innovation-funding organization RVO in 2015 for the energy system integration of the ECOVAT network balancing system. Meanwhile, it received support from BOM business development in the province of Noord-Brabant, worked together with various higher education organizations and joined the Dutch storage platform Energy Storage NL. Ecovat developed the system further, both technically and economically, resulting in the production of pre-fab elements in 2015, wall components in 2016 and several pre-engineering projects, for instance in Wageningen Benedenbuurt and Arnhem Ons Dorp. The finalization of the demo plant in Uden took place in 2017. In 2016, the company started participating in new platforms and projects, such as the Frisse Dingen, Dutch platform for sustainable innovation, the flexible heat and power H2020 project consortium and the talent for energy transition project. After the patent for the wall part of Ecovat in 2016, the system as a whole was patented in 2018 and certificated in 2018 (ISO 9001 and VCA certificates). In early 2020, Ecovat was also certified as a B corporation, making the startup company one of the worldwide frontrunners of for-profit companies with a high social and environmental performance [111].

A next step in the development of Ecovat was the improvement of the software, funded by the European regional development fund and regional funds and a Berenschot study on the system consequences and saving potential of ECOVAT and robotization of the production in 2018.

In 2019, ECOVAT successfully launched an issue of shares in NPEX ( $€ 1.26$ million). Despite an intensive preparatory trajectory successfully aligning all relevant actors and aspects (local government, politics, safety, cost efficiency proof etc.) of the first large-scale Ecovat Ons dorp project in Arnhem (claimed to become the most energy innovative neighborhood of NL), it was cancelled unexpectedly in June 2019 by the commissioner (SIZA) as the number of houses reduced from 550 to 175, making Ecovat no longer cost-effective.

In conclusion, during the step-by-step development of these technologies, both companies succeeded in organizing networks, cooperation with all kinds of societal parties, and receiving financial and other support. The two technologies and companies have some striking similarities. Both are seen as promising technologies for environmental friendly energy provision at local levels. Various societal actors such as universities, grid providers and governments expressed their support by funding and cooperation, and both technologies have won various awards. Both innovative storage technologies have similar organizational characteristics as well. They are both developed in-house, led by their 'inventor-entrepreneur' - in both cases a creative, socially engaged individual (one an engineer and the other an architect). Both technologies now have reached the stage of working prototypes and both startup companies developed their own commercial production processes. However, the companies and technologies differ as well. There are two main differences. First, Ecovat offers an integral solution. The company offers the main technology, options for financing, smart control as well as operation 
services and contracts. Although Ecovat is flexible in functionalities and size, a minimum size and low temperature district heating networks are required to make it financially more attractive. DrTen does not offer an integrated solution. The company is confined to the technical functioning of the battery and does not regard smart control (ICT) as part of its business. Second, there is a difference regarding the financial position of both companies. Ecovat is financially more robust (in 2018: turnover EUR 4 million and profit of EUR 1 million) [112]. Their pilot projects generate larger amounts of cash-flow (e.g., TKI EUR 4 million), and in April 2019 the company successfully issued shares (EUR 1.26 million) in the Dutch NPEX stock exchange. DrTen (turnover about EUR 1 million) finances the development and production of testbatteries primarily through participation in publicly funded energy pilot projects and with consultancy and demo-battery assigments.

\subsection{Actor Analysis}

For both technologies and companies, the similar type of actors are relevant or even crucial. We already mentioned the importance of municipalities, other governments, grid operators and universities for the funding, cooperation and further development of the technologies. In this context, actors refer to people or citizen's organisations, industries, or other private parties and governmental institutions that can affect or are affected by these technologies. Directly affected actors are households and communities, as well as energy system actors which are related to the installation of the technology, such as municipalities and grid operators where it will be installed as well as material suppliers and distributors. Public authorities, such as regulatory agencies, such as ACM, authorities for consumers and market, and DNV-GL, responsible for standard setting, as well as ministries and municipalities, may directly affect technological development through the introduction of new rules or subsidies or by creating enabling or inhibiting an environment for technology implementation. Both technologies have been certified by DNV-GL. Knowledge institutions, technology or material providers and transport companies may also be influential. In particular, in the case of Ecovat, the alignment of new and already existing technologies for the construction and functioning of the storage system was an important elment of technology development. Both DrTen ${ }^{\circledR}$ and Ecovat ${ }^{\circledR}$ joined the Dutch industry association EnergystorageNL, which is actively lobbying for a better regulation for energy storage in the Netherlands and support or aligned storage options. Figures 3 and 4 illustrate an overview of the various actors that play an important role in the socio-technical alignment of DrTen ${ }^{\circledR}$ and Ecovat ${ }^{\circledR}$, respectively.

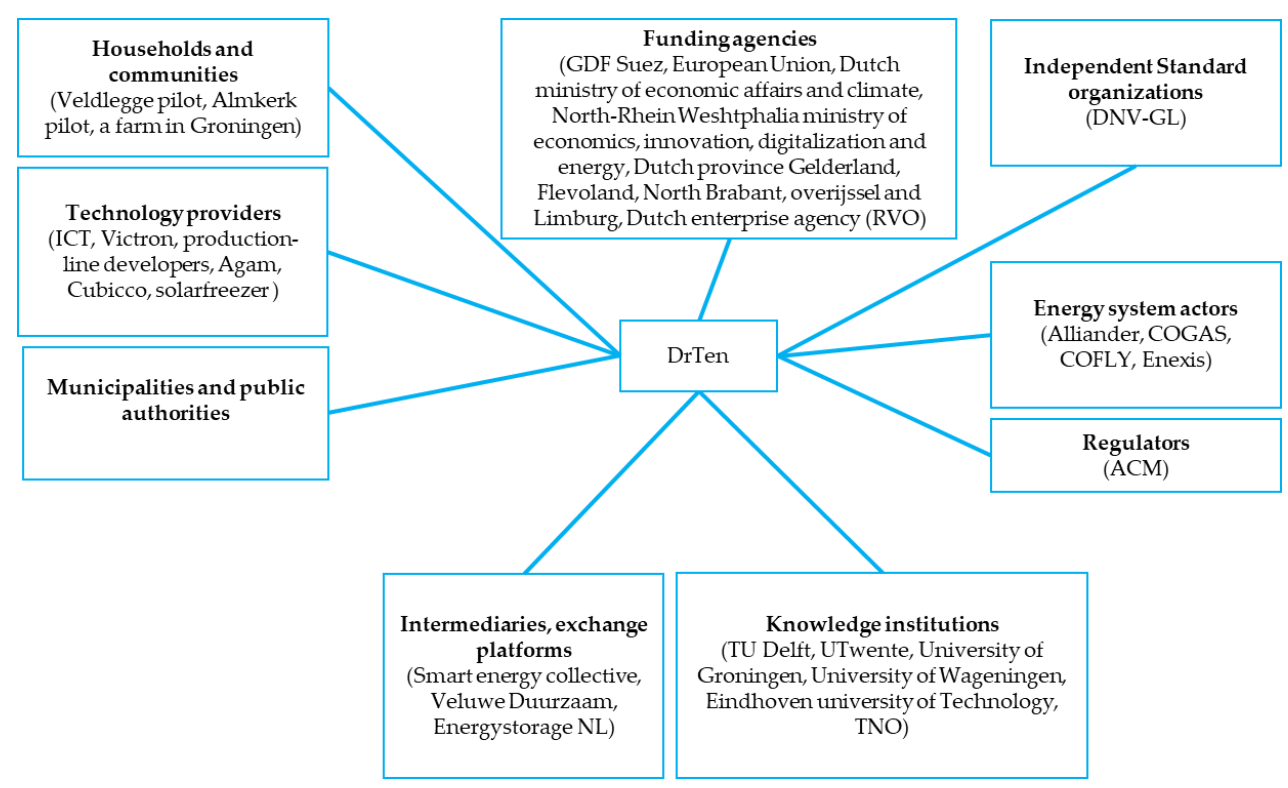

Figure 3. Actor mapping of DrTen ${ }^{\circledR}$. 


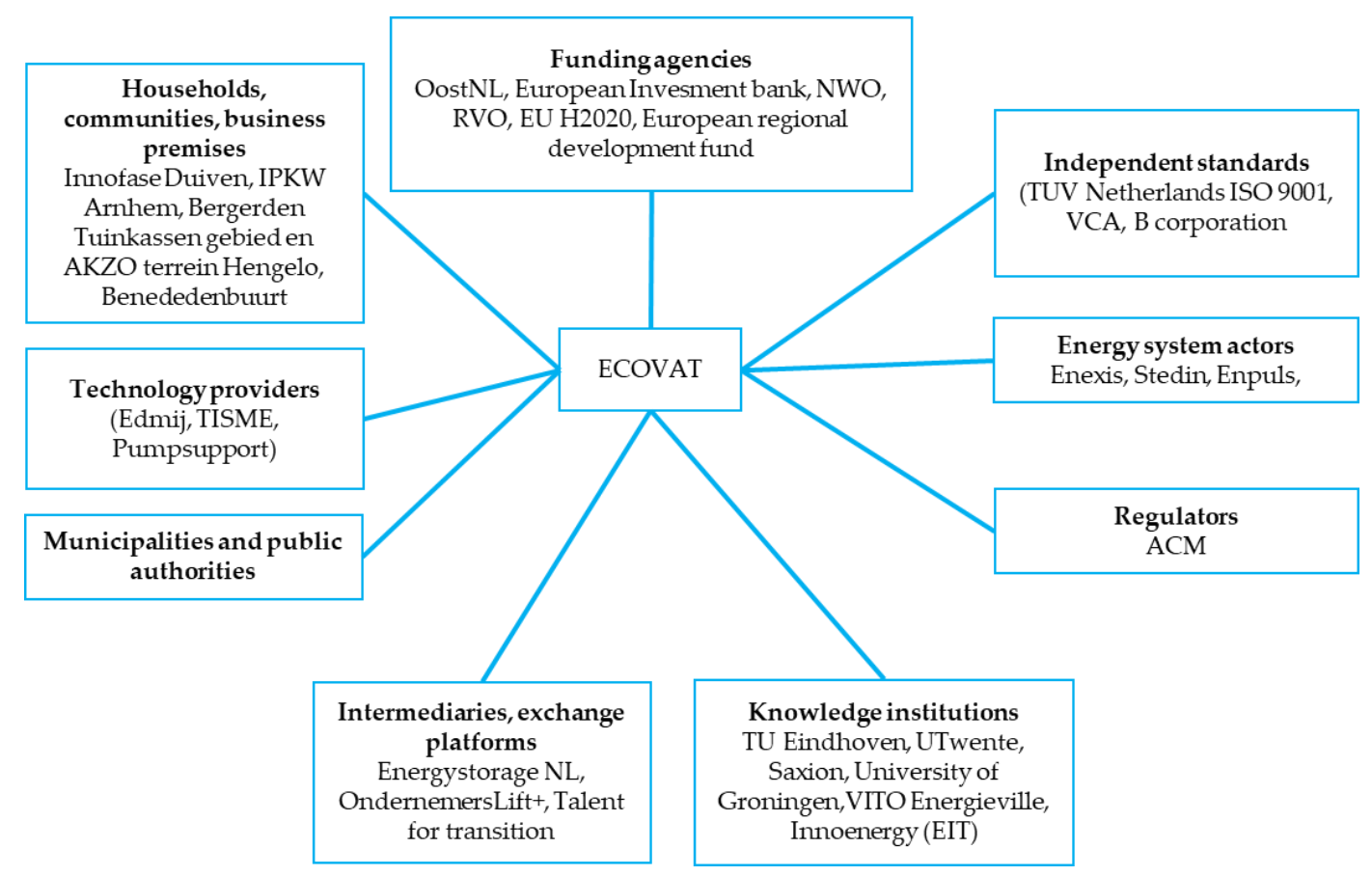

Figure 4. Actor mapping of Ecovat ${ }^{\circledR}$.

The relationship with energy system actors like TSOs and DSOs is more complex and ambigious. Ecovat can fulfill a variety of functions in the future energy system. Although ecovat ${ }^{\circledR}$ itself is a stand-alone technology, a preference for a total system concept by the technology developer is observed due to techno-economic complexities such as high upfront costs as well as operational requirements. As technical functionalities are starting to become clear, different application areas are being envisoned, namely short-term storage, seasonal storage, storage of waste heat and electricity and the production and transport of heat. Based on these funcationalities, power to heat as well as heat to power application are foreseen, although the latter will be feasible only under a very high share of renewable energy in the energy mix for efficiency reasons. Ecovat ${ }^{\circledR}$ also has the potential to take active participation in balancing markets, mainly to avoid the curtailement of renewables or peak demand due to electrication of the heating sector. For example, a recent study shows the cost-saving potential of Ecovat ${ }^{\circledR}$ due to avoided grid reinforcement and peak power plants [113]. Recently, potential application in agri-food sector has also been explored.

The focus of DrTen ${ }^{\circledR}$ to date has been on the technology development of sea-salt batteries for home owners and neighbourhoods. Increasing attention has been paid to the balance of the components such as charge controllers, energy management systems, battery management systems and inverters, and in some pilotprojects, Dr. Ten batteries were seen as a tool for balancing and peakshaving in smart local microgrids (Heeten and Interreg project). DrTen ${ }^{\circledR}$ has to work together with several technology developers in order to make it interoperable with the existing balance of components in the grid market.

\subsection{Use Cases in Local Communities}

The adoption process of Ecovat ${ }^{\circledR}$ and DrTen ${ }^{\circledR}$ community energy storage by local communities in the Netherlands was followed in the form of embedded case studies. At this level of envisioned use of the new technology in real life situations, both use cases showed a high level of alignment dynamics. A potential technology adoption of Ecovat ${ }^{\circledR}$ was discussed in a series of meetings in the local community of Benedenbuurt in the city of Wageningen. DrTen ${ }^{\circledR}$ seasalt batteries were foreseen to be installed in one household first followed by 7 and then 24 out of the 47 households in the neigbourhood of Veldegge, in the village of Heeten, part of a pilot of the so-called Gridflex project [89]. As delays were 
faced in ICT/technology integration, 3 houses were set so far but the rest are expected to follow in the near future with improved quality. In Table 1, observations from both of these use cases are presented.

Table 1. Observations from community use cases Benedenbuurt $\left(\right.$ Ecovat $\left.^{\circledR}\right)$ and Heeten $\left(\operatorname{DrTen}^{\circledR}\right)$.

\begin{tabular}{|c|c|c|}
\hline & Ecovat ${ }^{\circledR}$ (Benedenbuurt) & DrTen ${ }^{\circledR}($ Heeten $)$ \\
\hline Initiators & $\begin{array}{l}\text { Charismatic, creative idealist (resident) } \\
\text { (heteregoneous citizens) }\end{array}$ & $\begin{array}{c}\text { Combination of smart strategist (Escozon) } \\
\text { and charismatic resident (Endona) } \\
\text { (heterogeneous citizens) }\end{array}$ \\
\hline Stakeholders/organisation & $\begin{array}{l}\text { Only local stakeholders, little involvement } \\
\text { of traditional energy regime actors }\end{array}$ & $\begin{array}{l}\text { Involvement of combination of local } \\
\text { stakeholders and energy regime actors }\end{array}$ \\
\hline $\begin{array}{l}\text { Organisation/problem } \\
\text { definitions }\end{array}$ & $\begin{array}{l}\text { Fuzziness regarding who is responsible, } \\
\text { inequalities of paid and volunteer } \\
\text { workers, ad hoc incidental yet successful } \\
\text { financing/problem definitions shift easily }\end{array}$ & $\begin{array}{l}\text { Different roles are clear, All projects } \\
\text { participants and materials are financed. } \\
\text { Much alignment in problem definitions. }\end{array}$ \\
\hline $\begin{array}{l}\text { Involvement of } \\
\text { users/residents }\end{array}$ & $\begin{array}{l}\text { Users become more strongly organised } \\
\text { during the process/now growing group of } \\
\text { residents on drivers seat, } \\
\text { discussions on ownership }\end{array}$ & $\begin{array}{l}\text { Users/residents: very high participation } \\
\text { but mainly in limited user role. More } \\
\text { active contribution can grow in next } \\
\text { phase of project }\end{array}$ \\
\hline Tensions/conflicts & $\begin{array}{l}\text { Between energy cooperative and } \\
\text { interested commercial actors }\end{array}$ & $\begin{array}{l}\text { DSO's interest initially in conflict with } \\
\text { vision of 'net-zero behind the transformer' }\end{array}$ \\
\hline Material redefinitions & $\begin{array}{l}\text { Reframing Ecovat }{ }^{\circledR} \text { as logistic problem } \\
\text { (number of trucks) }\end{array}$ & $\begin{array}{l}\text { Battery safety was foregrounded/slow } \\
\text { development of the linkage of seasalt } \\
\text { battery to theICT system caused tension } \\
\text { in the project but was improved later. }\end{array}$ \\
\hline
\end{tabular}

In the following paragraph, we will present three elements of the alignment dynamics. First, the orgnization and empowerment of the citizen group, second, the role of the companies, and third, the involvment of other actors at the local level. The wider societal context, the flexibility of the technology and the technologcal infrastructure will be discussed in next paragraphs.

In both neighbourhoods, Heeten and Benedenbuurt, active citizens took the initiative for a more sustainable local energy system. They had other things in common. Both were interested in new technologies, which resulted in the plan to install sea salt batteries (Heeten) or Ecovat ${ }^{\circledR}$ (Benedenbuurt). Both shared an entrepeneurial attitude and are active networkers. Despite these similarities, development in both villages followed different pathways, resulting in different roles for the storage technologies. Benedenbuurt is a typical bottom-up citizens' initiative. Engaged citizens found each other during a sustainability street challenge in 2015. When the sewage pipes in the neighborhood had to be replaced, one creative citizen developed the initial idea to install a district heating network with an Ecovat ${ }^{\circledR}$ and associated system as heat source. He contacted the Wageningen municipality, who were very supportiveof this idea, as it fitted well in their ambitous sustainabilty policy. Because the Housing association owned a substantial number of houses in the neighbourhood (a total of about 450 households), they were asked to join. Soon, a working group was created with representatives of the Wageningen municipality, the housing corporation, the citizens and a representative from a neighbouring energy collective. Simultaneously, in the neighbourhood itself the initiating resident together with a small group of involved residents took the initiative to create an energy cooperative in the neigbourhood. The co-operative Warmtenet Oost Wageningen (WoW) was founded in 2018 and has, in early 2020, about 150 members (one third of the households in Benedenbuurt).

After ample discussion, the working group agreed on the replacement of the gas grid by a collective district heating system, in which Ecovat ${ }^{\mathbb{R}}$ was supposed to play a crucial role. Subsequently, various gatherings were organized. The working group visited Ecovat ${ }^{\circledR}$ company several times to see the pilot in Uden and to discuss the option to install a Ecovat ${ }^{\circledR}$ in the neigbourghood. Ecovat ${ }^{\circledR}$ was asked to make a design for an Ecovat ${ }^{\circledR}$ and to present it in the town hall of Wageningen. Ecovat ${ }^{\circledR}$ presented various options for citizens to participate, as a co-owner or shareholder, for instance, and suggested options for the topology of the heating grid. In general, the citizens and local policy makers welcomed the innovative idea of an Ecovat ${ }^{\circledR}$ seasonal storage that used the summer heat to warm dwellings in winter. However, the question of Ecovat ${ }^{\circledR}$ 's suitability in this 1950 s neighborhood with the wide 
spread of low-rise houses and a low degree of heat insulation of the houses was also on the table from the beginning. High-temperature heating and a wide heat infrastructure is not optimal for Ecovat ${ }^{\circledR}$. A concentration of well insulated houses makes a Ecovat ${ }^{\circledR}$-based heating system more efficient. For that reason, the working group asked a consultancy to make several scenarios for heating the neighborhood, one of which was Ecovat ${ }^{\circledR}$. This scenario study made clear that it is very difficult to make scenarios because of many uncertainties. For that reason, it is hard to say which scenario is most risky in terms of finances, but individual heat pumps turned out to be the most expensive. The consultancy found that in terms of sustanaibility Ecovat ${ }^{\circledR}$ is the most attractive option. However, it was concluded that, for this neighborhood, with its widespread, poorly insulated houses, Ecovat ${ }^{\circledR}$ was not the first-choice option. In addition, some inhabitants feared the many heavy trucks needed for transporting the soil out for the construction of the large Ecovat ${ }^{\circledR}$ in the middle of the neigbourhood. After consulting the key members of the working group, the housing corporation, the municipality and the citizens, it was decided to focus on other options, in particular a high-temperature system, heat-cold storage and a central heat pump. This proposal was also presented and accepted in one of the residents' meetings. At that time, it was proposed to start negotiations with various commercial companies, such as Engie, but not all citizens agreed on that, because they were afraid to lose control of the project. To be able to work on the project in a professional way, the Wageningen municipality decided to pay some of the initiators of the project.

Therefore, citizens appeared to be able to organize around a technology, i.e., Ecovat, and to gather relevant knowledge, inspired by some entrepeneurial technology and the interested and passionate citizens. They were able to grow and to involve several other local actors, firstly the housing association and the municipality and to discuss with the Ecovat company, supported by a consultancy. Despite close cooperation between citizens, the municipality and the housing association, the division of responsibilities was not always clear. It took time to found an energy cooperative, to develop a team of paid professionals and to define the different roles of volunteers compared to these professionals. In addition, tensions arose about the inclusion and roles of interested commercial actors, such as traditional energy regime actors. However, close collaboration combined with strong citizen involvement led, in autumn 2018, to a successful application as a 'voorbeeldwijk' (for example, a natural-gas free neighbourhood) for the Dutch policy to stop natural gas heating completely by 2050, involving millions of euros in subsidy [114]. By that time, Ecovat ${ }^{\circledR}$ did not figure anymore in the plans.

In Heeten, a small group of highly involved citizens realized, via the local energy cooperative (Endona) and energy service company (Escozon), various 'big' sustainability projects. One such project is the installation and exploitation (local self-consumption) of a solar PV field in Heeten. Another is an exemption to the Dutch electricity law (e.g., allowing experiments such as local grids and local energy markets). A third project is the Gridflex project that aimed to experiment with local flexibility and a local energy market in a Heeten neigbourhood of Veldegge with 47 relatively new houses. For the Gridflex project, a consortium with the Endona, Escozon, a DSO (Enexis), an ICT company, the University of Twente, Buurkracht (an organization specialized at activating groups of residents for sustainable energy) and DrTen ${ }^{\circledR}$. The aim was to explore options for grid flexibility options at local level, by using storage with batteries and tge coordination of the use and production of renewable energy among residents. The residents of the neigbourhood were asked to participate in this project by changing their behaviour and allow technical adjustments. In the period 2016-2020, the consortium partners came together regularly to discuss the project progress. One of the main problems was the functioning of the sea-salt battery in real-life conditions. Despite good test results in lab conditions, it took a long time to make the battery function in real-life conditions. In particular, the safety of the battery asked for some discussions, as well as the rate of charging and discharging as grid operators, users, and technology suppliers needed time to set agreements on steering and user protocols. It led to a different version of the battery, the powdered battery (higher energy density) and non-powdered coated version with higher (dis)charging rates. Moreover, linking the DrTen batteries to regular Battery Management System and inverters developed for li-ion batteries was a real issue and took 
time. This failed linkage caused some tension in the consortium, as the cause of the malfunctioning system was difficult to find. In the end, with half a year prolongation and help of some external experts, the roadmap to integration was found. As a temporary solution, virtual batteries were simulated and, in the last half year, a few Li-ion batteries were also installed in addition to DrTen batteries. DrTen batteries could act on local level soon but more professional integration took more than two years. First systems are running with success since the end of 2019.

Other goals of the Gridflex project, such as gaining insight into the dynamics of local energy markets and the optimization of flexibility in co-ordination with the users faded into the background. The active involvement of the Veldegge residents in performing energy flexibility and experiment with local energy markets was hardly realized. This was especially disappointing for the GridFlex consortium, as Endona and Buurkracht put a lot of effort into succesfully realisering a staggering 100\% participation in the Veldegge neighbourhood at the start of the project. The residents had a positive attitude towards the DrTen battery, although other types of batteries were also welcomed. However, the residents had no possibility of controlling the batteries; they only got information on the battery status through the app.

In the end, the project could conclude that peakshaving combined with more self-consumption of self-produced solar leads to $10-20 \%$ less cost at the transformator (depending on the reimbursment by the DSO under the experimentation conditions). The 'earned money' was given to the residents and they decided to allocate this money to a community goal, the purchase of a AED for their neighborhood. For DrTen ${ }^{\circledR}$ this pilot in the end was fruitful as they learned a lot about aligning the new battery to existing and available control technology. The ongoing discussions on 'false' expectations and the discongruent definitions of what a 'working battery' entails, further highlighted the importance of socio-technical alignment.

Besides this choice for a particular technology, the problems with technical alignment and the relatively small role of citizens, we observed that, just as in the Benedenbuurt case, tensions arose in the Heeten case about the inclusion and roles of interested commercial actors and traditional energy regime actors, because of conflicting visions (e.g., net-zero behind the transformer, see Table 1). In contrast to the Benedenbuurt case, the local government was not included, which may reduce its moral, political and financial involvement and responsibility.

\subsection{Socio-Technical Alignment Dynamics}

In both energy storage technologies, socio-technical alignment dynamics have been observed. The innovator of DrTen ${ }^{\circledR}$ was looking for a cheap and environmentally friendly way to store energy to provide affordable energy access in Africa. Accordingly, certain values such as environmental friendliness, safety and afforability are already embedded in the design of $\operatorname{DrTen}{ }^{\circledR}$ batteries. At the same time, DrTen ${ }^{\circledR}$ batteries are engaged in several pilots and research projects such as gridflex Heeten as well as the Germany-Netherland cross-border project (INTERREG) [89,115]. In the gridflex project, DrTen ${ }^{\circledR}$ had to align interoperability issues with other energy management systems, battery management systems and inverter technologies developers. Moreover, to improve the charging and discharging rate, the cell configuration of the batteries had to be changed and powdered DrTen ${ }^{\circledR}$ had to be developed. In this process, the safety standard for residential use through DNV-GL was also obtained. DrTen ${ }^{\circledR}$ also obtained membership of Dutch industry association, EnergystorageNL, which is currently lobbying for better regulation for energy storage in the Netherlands [116].

Environmental values such as sustainable and reliable heating and cooling are embedded in the design of Ecovat ${ }^{\circledR}$. In several engagements of Ecovat ${ }^{\circledR}$ in pilot projects (e.g., Ons Dorp), feasibility studies (e.g., Benedenbuurt) and reports are observed. A working prototype of small Ecovat ${ }^{\circledR}$ has been successsfully tested in Uden. Technical innovation based on this demonstration includes improved construction methods, roofs as well as a hybrid system with a traditional exchanger for peak demand. For logistical reasons, manufacturing has been moved from Uden to Oss, close to the waterways. Given the very high upfront costs, Ecovat ${ }^{\circledR}$ developed a total systems concept including financing, energy 
management systems (ecovat software 2.0), and operation and distribution through subsidaries. To avoid the very long time needed for planning approvial (approximately 40 weeks), Ecovat ${ }^{\circledR}$ strategically managed to be included in the new urban master planning of Hague.

Despite their potential, both technologies have to overcome some problems to improve their alignment with societal actors, structures and processes. Ecovat ${ }^{\circledR}$ was welcomed enthusiastically in Benedenbuurt. However, Ecovat ${ }^{\circledR}$ could not meet the requirements of the local stakeholders here, who asked for a high-temperature heating system. In addition, several citizens feared the construction activities and some labeled Ecovat as a "logistic nightmare". In Arnhem, where Ecovat ${ }^{\circledR}$ succesfully negotiated with a large care institution, the municipality and many other relevant stakeholders, and received permission to place a Ecovat at the care institution, the court decided to forbid the chosen transport route of trucks through their neighborhood. A group of local residents feared burdening and unsafe transport of the approximately $5000 \mathrm{~m}^{3}$ of soil by heavy trucks [117]. An alternative transport route was available, but not put into practice, as the commissioner stopped the whole project.

Ecovat ${ }^{\circledR}$ is well aligned to existing technological systems. The Ecovat ${ }^{\circledR}$ system can be connected to all kinds of heat, information and electricity systems. The only problem is the localisation and design of buildings, in particular in old neighborhoods. Old and widespread small buildings are difficult to align with Ecovat ${ }^{\circledR}$, compared to the green field of compact, concentrated new buildings. It is, however, possible to use Ecovat ${ }^{\circledR}$ in a high-temperature district heating network (thus avoiding investments in the renovations/insulation of households) but this will be expensive and less sustainable. This is also related to the design of the Ecovat ${ }^{\circledR}$ configuration as a whole: the interwovenness of size, efficiency and logistics. The ecovat ${ }^{\circledR}$ system wins a great deal of cost-effiency by increasing the size. There is a tendency to increase the minimum size too (in 2016: $15 \mathrm{~m}$ diameter and $15 \mathrm{~m}$ deep) In 2020: $30 \mathrm{~m}$ diameter and $30 \mathrm{~m}$ deep). This too implies a huge increase in transport and logistic needs during the construction period, which clearly can raise strong objections from local residents. Although Ecovat ${ }^{\circledR}$ tries to limit the nuisance for the neighborhood, e.g., by prefabrication of elements, this aspect is likely to remain a sensitive element in aliging dynamics as it can easily invoke resistance, especially in residential areas. A continuous sharp eye and ear is crucial in the alignment strategy.

DrTen ${ }^{\circledR}$ was welcomed by local citizens. Here, too, citizens are, in general, positive about its environmental friendliness. Ownership is not a problem; batteries can be owned both by individuals as well as communities. The local energy community in Heeten highly values and stimulates local ownership of the local energy infrastrucutres. DrTen batteries still face interoperability challenges with existing technological systems, but progess is being made lately. The specific battery characteristics cause difficulties in the integration of existing smart steering technology of the batteries at first.

Because of the abandoning of Dutch natural gas, heat production will increasingly be electrified. The rising share of green electricity production implies rising seasonal gaps, which probably will make Ecovat ${ }^{\circledR}$ more profitable. It is not certain how markets and the regulation of markets will develop, however [118]. Crucial in Ecovat's business model is the long-term availability of cheap surplus wind and solar energy, which will eventually outweigh the high investment costs. DrTen ${ }^{\circledR}$ can also be more profitable in future. Now, electricity storage is financially not interesting due to FIT regulation, but this regulation is being gradually phased out in the period 2021-2030.

Both Ecovat ${ }^{\circledR}$ and DrTen ${ }^{\circledR}$ also claim avoided future network costs for DSOs and TSOs, as less grid enforcement is needed in the case of the widespread implementation of (seasonal) local storage. However, the storage costs are made by the local actors and citizen communities, and there is no clear regulation how distributed (future) profits and costs will be aligned to different stakeholders.

\section{Conclusions and Discussion}

There are techno-economic as well as socio-institutional challenges for implementing innovative community energy storage technologies in the energy system. In community energy storage, both technical and social innovation go hand in hand. The dynamics of interaction between the actors and technological innovation processes in community energy storage makes its implementation complex. 
In the process of the adoption and use of energy storage technologies in local energy communities, new user-inspired innovations are possible. Such innovation can be in the governance and operation of the energy storage system or on further technological improvement based on the feedback of users and other stakeholders. A careful alignment of technical-technical, socio-technical, and social-social articulation is required for the successful integration of community energy storage in the energy system. Socio-technical alignment is critical, as technology shapes the society, and society in turn influences the technology development. Enabling regulatory, policy and market environment are also important for the socio-technical alignment of innovative energy storage technologies. A level playing field can be created for energy storage, for example, by removing the double taxes, as storage is still considered as a load, as well as by a fair costs and benefits allocation of avoided network costs due to energy storage among consumers/prosumers and network system operators.

Our cases showed that, in different contexts, and regarding different technologies, problems with both technological and social alignment arise. Both technologies are promising in terms of sustainability and locality. However, both technologies faced resistance or problems, sometimes unexpectedly. An RRI analysis of DrTen ${ }^{\circledR}$ and Ecovat ${ }^{\circledR}$ demonstrated several technological-economic, regulatory and social challenges and requirements at various levels. For all these aspects and levels, most actors are in the first stage of a learning process.

Ecovat ${ }^{\circledR}$ is a well developed technology and fits well in existing technological systems. However, it has been difficult to implement it to date, because of high investment costs, some unclarity or uncertainty on participation options and storage policy in the long-run and the duration and thoroughness of the construction work. Modification of the technology, more options for participation and early negotiations regarding the means of construction could improve alignment. As we have seen, however, stable social and governmenental configuration at a local level are required to enable these types of technology and to organize learning processes.

DrTen ${ }^{\circledR}$ sea salt batteries gave good results in first peak-shaving experiments (both consumption and solar-PV generation peaks) but integrationin existing technological systems took longer time. This was one of the main reasons that implementation of only few systems was possible though improvements are expected.Yet, the pilot project in Heeten learned DrTen and other project actors a lot about any technical misalignment. The technology is flexible and easy to implement at household and neighbourhood levels. Making the battery part of a local flexible energy use-production-storage system requires new governance models and learning processes at the local level. Regulation and certainity on prices are crucial contextual factors for further development.

In our view of community energy storage cases as responsible inclusive innovations, we made some interesting observations (tensions) in socio-technical alignment. First, radical innovations are more likely from a non-regime actor, new actors in the energy system. In the case of Heteen, these new actors were the energy service company Escozon, energy co-operative Endona, technology proivders DrTen ${ }^{\circledR}$ and ICT. In the case of Benedenbuurt, local energy co-operative and Ecovat ${ }^{\circledR}$ were the new actors. Second, radical innovation is also about empowering and engaging citizens and user communities in the process, thereby creating new socio-technical configurations. For example, in the case of the Heteen battery, control was not allowed, but it gave the neighborhood full decision on financial benefits allocation, which was a result of network costs reductions due to peak shaving in the neighbourhood microgrid. For Benedenbuurt, participaton options for an Ecovat ${ }^{\circledR}$ were given, but the Benedenbuurt energy co-operative/residents were, at the beginning, too inexperienced to handle such big upfront investment costs (EUR 3.5 million excluding the costs of a district heating network). However, such a capability was quickly developed with the help of government subsidy for a natural gas-free neighbourhood pilot. Both cases show that, with the availability and support of energy service companies (third-party experts), the local energy initiatives can grow to ownership and exploitation.

The relative newcomers Ecovat and DrTen introduced interesting and promising sustainable technologies, which may help to solve energy storage problems at a local scale. Both companies have been able to build networks around their technology, including energy cooperatives, large companies, 
municipalities and DSOs. For that reason, both have been able to further improve their technology. The involved energy cooperatives have been heavily involved in the pilots around these technologies. This resulted in empowerment because they were seen as interesting partners, which could help to test and develop new technologies, and because they developed as experts in local energy systems. For that reason, energy cooperatives may be a stimulating factor for social-technological innovations and in the energy transition (see [38]), but this requires quite a long period of involvement, patience and capacity-building to be able to co-create technologies which go along with relatively high investments in infrastructure or interoperability with existing technologies.

Author Contributions: Conceptualization, B.P.K., E.v.O. and H.v.d.W.; methodology, B.P.K., E.v.O. and H.v.d.W.; writing—original draft preparation, B.P.K.; writing—review and editing, B.P.K., E.v.O. and H.v.d.W.; visualization, B.P.K.; supervision, E.v.O. and H.v.d.W.; project administration, H.v.d.W.; funding acquisition, E.v.O. and H.v.d.W. All authors have read and agreed to the published version of the manuscript.

Funding: This research is part of the Community Responsible Innovation in Sustainable Energy (CO- RISE) project [29] and is funded through the social responsible innovation program of The Netherlands Organization for Scientific Research, the Netherlands. Grant number: NWO-MVI 2016[313-99-304].

Acknowledgments: We are thankful to the Gridflex andBenedenbuurt project consortium for the possibilities to take part in all the meetings, their openness to our questions and access to the project documentation. In addition, we are grateful to the studied SME's Ecovat and Dr Ten for providing open and transparent project information.

Conflicts of Interest: The authors declare no conflict of interest. The funders had no role in the design of the study; in the collection, analyses, or interpretation of data; in the writing of the manuscript, or in the decision to publish the results.

\section{References}

1. Kelly, S.; Pollitt, M.G. The local dimension of energy. In The Future of Electricity Demand: Customers, Citizens and Loads; Pollitt, M.G., Ed.; Cambridge University Press: Cambridge, UK, 2011; pp. 249-275.

2. Vargas, M.; Davis, G. World Energy Scenarios 2016; World Energy Council: London, UK, 2016.

3. Koirala, B.P.; Koliou, E.; Friege, J.; Hakvoort, R.A.; Herder, P.M. Energetic communities for community energy: A review of key issues and trends shaping integrated community energy systems. Renew. Sustain. Energy Rev. 2016, 56, 722-744. [CrossRef]

4. Devine-Wright, P. Community versus local energy in a context of climate emergency. Nat. Energy 2019, 4, 894-896. [CrossRef]

5. Koirala, B.P.; van Oost, E.; van der Windt, H. Community energy storage: A responsible innovation towards a sustainable energy system? Appl. Energy 2018, 231, 570-585. [CrossRef]

6. Kyriakopoulos, G.L.; Arabatzis, G. Electrical energy storage systems in electricity generation: Energy policies, innovative technologies, and regulatory regimes. Renew. Sustain. Energy Rev. 2016, 56, 1044-1067. [CrossRef]

7. Manfren, M.; Caputo, P.; Costa, G. Paradigm shift in urban energy systems through distributed generation: Methods and models. Appl. Energy 2011, 88, 1032-1048. [CrossRef]

8. Koirala, B.P.; Araghi, Y.; Kroesen, M.; Ghorbani, A.; Hakvoort, R.A.; Herder, P.M. Trust, awareness, and independence: Insights from a socio-psychological factor analysis of citizen knowledge and participation in community energy systems. Energy Res. Soc. Sci. 2018, 38, 33-40. [CrossRef]

9. Kalkbrenner, B.J.; Roosen, J. Citizens' willingness to participate in local renewable energy projects: The role of community and trust in Germany. Energy Res. Soc. Sci. 2016, 13, 60-70. [CrossRef]

10. Van der Waal, E.C.; Das, A.M.; van der Schoor, T. Participatory Experimentation with Energy Law: Digging in a 'Regulatory Sandbox' for Local Energy Initiatives in the Netherlands. Energies 2020, 13, 458. [CrossRef]

11. Gregg, J.S.; Nyborg, S.; Hansen, M.; Schwanitz, V.J.; Wierling, A.; Zeiss, J.P.; Delvaux, S.; Saenz, V.; Polo-Alvarez, L.; Candelise, C.; et al. Collective Action and Social Innovation in the Energy Sector: A Mobilization Model Perspective. Energies 2020, 13, 651. [CrossRef]

12. Horstink, L.; Wittmayer, J.M.; Ng, K.; Luz, G.P.; Marín-González, E.; Gährs, S.; Campos, I.; Holstenkamp, L.; Oxenaar, S.; Brown, D. Collective Renewable Energy Prosumers and the Promises of the Energy Union: Taking Stock. Energies 2020, 13, 421. [CrossRef]

13. Kloppenburg, S.; Smale, R.; Verkade, N. Technologies of Engagement: How Battery Storage Technologies Shape Householder Participation in Energy Transitions. Energies 2019, 12, 4384. [CrossRef] 
14. Dilger, M.G.; Konter, M.; Voigt, K.-I. Introducing a co-operative-specific business model: The poles of profit and community and their impact on organizational models of energy co-operatives. J. CoOper. Organ. Manag. 2017, 5, 28-38. [CrossRef]

15. EU Clean Energy for All Europeans-Energy-European Commission. Available online: /energy/en/topics/ energy-strategy-and-energy-union/clean-energy-all-europeans (accessed on 24 July 2019).

16. Van der Schoor, T.; Scholtens, B. Power to the people: Local community initiatives and the transition to sustainable energy. Renew. Sustain. Energy Rev. 2015, 43, 666-675. [CrossRef]

17. Lowitzsch, J. Consumer Stock Ownership Plans (CSOPs)—The Prototype Business Model for Renewable Energy Communities. Energies 2019, 13, 118. [CrossRef]

18. RED II Directive (EU) 2018/2001 of the European Parliament and of the Council of 11 December 2018 on the Promotion of the Use of Energy from Renewable Sources; Publications office of the European Union: Luxembourg, 2018.

19. EMD II Directive (EU) 2019/944 of the European Parliament and of the Council of 5 June 2019 on Common Rules for the Internal Market for Electricity and Amending Directive 2012/27/EU; Publications office of the European Union: Luxembourg, 2019.

20. Koirala, B.P. Integrated Community Energy Systems. Ph.D. Thesis, Delft University of Technology, Delft, The Netherlands, 2017.

21. Parra, D.; Swierczynski, M.; Stroe, D.I.; Norman, S.A.; Abdon, A.; Worlitschek, J.; O’Doherty, T.; Rodrigues, L.; Gillott, M.; Zhang, X.; et al. An interdisciplinary review of energy storage for communities: Challenges and perspectives. Renew. Sustain. Energy Rev. 2017, 79, 730-749. [CrossRef]

22. Koirala, B.P.; van Oost, E.; van der Windt, H. Socio-Technical Innovation Dynamics in Community Energy Storage; CESUN Conference: Tokyo, Japan, 2018; pp. 1-8.

23. Maclaine Pont, P.; van Est, R.; Deuten, J. Shaping Socio-Technical Innovation through Policy; Rathenau Institute: Den Hague, The Netherlands, 2016.

24. EnergystorageNL National Actionplan on Energy Storage and Conversion; ESNL: Zoetermeer, The Netherlands, 2019.

25. IRENA Renewables and Electricity Storage: A Technology Roadmap for REMAP 2030; International Renewable Energy Agency: Abu Dhabi, UAE, 2015.

26. De Torres, P.M.A. An overview on strategic design for socio-technical innovation. Strateg. Des. Res. J. 2018, 11, 186-192. [CrossRef]

27. Konrad, K.; Böhle, K. Socio-technical futures and the governance of innovation processes-An introduction to the special issue. Futures 2019, 109, 101-107. [CrossRef]

28. Dong, S.; Kremers, E.; Brucoli, M.; Rothman, R.; Brown, S. Techno-enviro-economic assessment of household and community energy storage in the UK. Energy Convers. Manag. 2020, 205, 112330. [CrossRef]

29. Koirala, B.P.; van Oost, E. Local Energy Communities: Responsible Innovation Towards Sustainable Energy (CO-RISE). In Proceedings of the CTIT Symposium 2017: IoT is Ready. What about Us; University of Twente: Enschede, The Netherlands, 2017.

30. Koirala, B.P.; Hakvoort, R.A.; van Oost, E.C.; van der Windt, H.J. Community Energy Storage: Governance and Business Models. In Consumer, Prosumer, Prosumager; Academic Press: Cambridge, MA, USA, 2019; pp. 209-234. ISBN 978-0-12-816835-6.

31. Garud, R.; Karnøe, P. Bricolage versus breakthrough: Distributed and embedded agency in technology entrepreneurship. Res. Policy 2003, 32, 277-300. [CrossRef]

32. Ornetzeder, M.; Rohracher, H. User-led innovations and participation processes: Lessons from sustainable energy technologies. Energy Policy 2006, 34, 138-150. [CrossRef]

33. Ornetzeder, M.; Rohracher, H. Of solar collectors, wind power, and car sharing: Comparing and understanding successful cases of grassroots innovations. Glob. Environ. Chang. 2013, 23, 856-867. [CrossRef]

34. Seyfang, G.; Park, J.J.; Smith, A. A thousand flowers blooming? An examination of community energy in the UK. Energy Policy 2013, 61, 977-989. [CrossRef]

35. Bomberg, E.; McEwen, N. Mobilizing community energy. Energy Policy 2012, 51, 435-444. [CrossRef]

36. Seyfang, G.; Hielscher, S.; Hargreaves, T.; Martiskainen, M.; Smith, A. A grassroots sustainable energy niche? Reflections on community energy in the UK. Environ. Innov. Soc. Transit. 2014, 13, 21-44. [CrossRef]

37. Hargreaves, T.; Hielscher, S.; Seyfang, G.; Smith, A. Grassroots innovations in community energy: The role of intermediaries in niche development. Glob. Environ. Chang. 2013, 23, 868-880. [CrossRef] 
38. Van der Waal, E.; van der Windt, H.; van Oost, E. How Local Energy Initiatives Develop Technological Innovations: Growing an Actor Network. Sustainability 2018, 10, 4577. [CrossRef]

39. Verbeek, P.-P. Materializing Morality: Design Ethics and Technological Mediation. Sci. Technol. Hum. Values 2006, 31, 361-380. [CrossRef]

40. Winner, L. Do artefacts have politics? Daedalus 1980, 109, 121-136.

41. Owen, R.; Stilgoe, J.; Macnaghten, P.; Gorman, M.; Fisher, E.; Guston, D. A Framework for Responsible Innovation. In Responsible Innovation; Owen, R., Bessant, J., Heintz, M., Eds.; John Wiley \& Sons, Ltd.: Chichester, UK, 2013; pp. 27-50. ISBN 978-1-118-55142-4.

42. Stilgoe, J.; Owen, R.; Macnaghten, P. Developing a framework for responsible innovation. Res. Policy 2013, 42, 1568-1580. [CrossRef]

43. Timmermans, J. Mapping the RRI Landscape: An Overview of Organisations, Projects, Persons, Areas and Topics. In Responsible Innovation 3; Asveld, L., van Dam-Mieras, R., Swierstra, T., Lavrijssen, S., Linse, K., van den Hoven, J., Eds.; Springer International Publishing: Cham, Switzerland, 2017; pp. 21-47. ISBN 978-3-319-64833-0.

44. Rogers, J.C.; Simmons, E.A.; Convery, I.; Weatherall, A. Public perceptions of opportunities for community-based renewable energy projects. Energy Policy 2008, 36, 4217-4226. [CrossRef]

45. Walker, G.; Devine-Wright, P.; Barnett, P.; Burningham, K.; Cass, N.; Devine-Wright, H.; Speller, G.; Barton, J.; Evans, B.; Heath, Y. Symmetries, expectations, dynamics and contexts: A framework for understanding public engagement with renewable energy projects. In Renewable Energy and the Public: From Nimby to Participation; Earthscan; Routledge; Taylor \& Francis: London, UK, 2010; pp. 2-14. ISBN 1844078639.

46. Walker, G. What are the barriers and incentives for community-owned means of energy production and use? Energy Policy 2008, 36, 4401-4405. [CrossRef]

47. Walker, G.; Devine-Wright, P. Community renewable energy: What should it mean? Energy Policy 2008, 36, 497-500. [CrossRef]

48. Walker, G.; Simcock, N. Community Energy Systems. Int. Encycl. Hous. HomeElsevier 2012, 1, $194-198$.

49. Wirth, S. Communites matter: Institutional preconditions for community renewable energy. Energy Policy 2014, 1-11.

50. Koirala, B.; Chaves Ávila, J.; Gómez, T.; Hakvoort, R.; Herder, P. Local Alternative for Energy Supply: Performance Assessment of Integrated Community Energy Systems. Energies 2016, 9, 981. [CrossRef]

51. Koirala, B.; Hakvoort, R. Integrated Community-Based Energy Systems: Aligning Technology, Incentives, and Regulations. In Innovation and Disruption at the Grid's Edge; Academic Press: Cambridge, MA, USA, 2017; pp. 363-387. ISBN 978-0-12-811758-3.

52. Koirala, B.P.; Hakvoort, R.A.; Ávila, J.P.C.; Gómez, T. Assessment of Integrated Community Energy Systems. In Proceedings of the 2016 13th International Conference on the European Energy Market (EEM), Porto, Portugal, 6-9 June 2016; pp. 1-6.

53. Acosta, C.; Ortega, M.; Bunsen, T.; Koirala, B.; Ghorbani, A. Facilitating Energy Transition through Energy Commons: An Application of Socio-Ecological Systems Framework for Integrated Community Energy Systems. Sustainability 2018, 10, 366. [CrossRef]

54. Caramizaru, A.; Uihlein, A.; European Commission; Joint Research Centre. Energy Communities: An Overview of Energy and Social Innovation; Publications Office of the European Union: Luxembourg, 2020; ISBN 978-92-76-10713-2.

55. Van der Schoor, T.; Scholtens, B. Scientific Approaches of Community Energy: A Literature Review; Centre for Energy Economics Research (CEER): Groningen, The Netherlands, 2019; ISBN 978-94-034-1657-1.

56. Van der Schoor, T.; van Lente, H.; Scholtens, B.; Peine, A. Challenging obduracy: How local communities transform the energy system. Energy Res. Soc. Sci. 2016, 13, 94-105. [CrossRef]

57. Mendes, G.; Ioakimidis, C.; Ferrão, P. On the planning and analysis of Integrated Community Energy Systems: A review and survey of available tools. Renew. Sustain. Energy Rev. 2011, 15, 4836-4854. [CrossRef]

58. Romero-Rubio, C.; de Andrés Díaz, J.R. Sustainable energy communities: A study contrasting Spain and Germany. Energy Policy 2015, 85, 397-409. [CrossRef]

59. De Vries, G.W.; Boon, W.P.C.; Peine, A. User-led innovation in civic energy communities. Environ. Innov. Soc. Transit. 2016, 19, 51-65. [CrossRef] 
60. Moroni, S.; Alberti, V.; Antoniucci, V.; Bisello, A. Energy Communities in a Distributed-Energy Scenario: Four Different Kinds of Community Arrangements. In Smart and Sustainable Planning for Cities and Regions; Bisello, A., Vettorato, D., Laconte, P., Costa, S., Eds.; Springer International Publishing: Cham, Switzerland, 2018; pp. 429-437. ISBN 978-3-319-75773-5.

61. Gui, E.M.; MacGill, I. Typology of future clean energy communities: An exploratory structure, opportunities, and challenges. Energy Res. Soc. Sci. 2018, 35, 94-107. [CrossRef]

62. Espe, E.; Potdar, V.; Chang, E. Prosumer Communities and Relationships in Smart Grids: A Literature Review, Evolution and Future Directions. Energies 2018, 11, 2528. [CrossRef]

63. Barbour, E.; Parra, D.; Awwad, Z.; González, M.C. Community energy storage: A smart choice for the smart grid? Appl. Energy 2018, 212, 489-497. [CrossRef]

64. Van der Stelt, S.; AlSkaif, T.; van Sark, W. Techno-economic analysis of household and community energy storage for residential prosumers with smart appliances. Appl. Energy 2018, 209, 266-276. [CrossRef]

65. Roberts, B.P.; Sandberg, C. The Role of Energy Storage in Development of Smart Grids. Proc. IEEE 2011, 99, 1139-1144. [CrossRef]

66. Jolivet, E.; Heiskanen, E. Blowing against the wind-An exploratory application of actor network theory to the analysis of local controversies and participation processes in wind energy. Energy Policy 2010, 38, 6746-6754. [CrossRef]

67. Hargreaves, T. Practice-ing behaviour change: Applying social practice theory to pro-environmental behaviour change. J. Consum. Cult. 2011, 11, 79-99. [CrossRef]

68. Aune, M.; Godbolt, Å.L.; Sørensen, K.H.; Ryghaug, M.; Karlstrøm, H.; Næss, R. Concerned consumption. Global warming changing household domestication of energy. Energy Policy 2016, 98, 290-297. [CrossRef]

69. Devine-Wright, P.; Batel, S.; Aas, O.; Sovacool, B.; Labelle, M.C.; Ruud, A. A conceptual framework for understanding the social acceptance of energy infrastructure: Insights from energy storage. Energy Policy 2017, 107, 27-31. [CrossRef]

70. Jalas, M.; Hyysalo, S.; Heiskanen, E.; Lovio, R.; Nissinen, A.; Mattinen, M.; Rinkinen, J.; Juntunen, J.K.; Tainio, P.; Nissilä, H. Everyday experimentation in energy transition: A practice-theoretical view. J. Clean. Prod. 2017, 169, 77-84. [CrossRef]

71. Ryghaug, M.; Toftaker, M. A Transformative Practice? Meaning, Competence, and Material Aspects of Driving Electric Cars in Norway. Nat. Cult. 2014, 9, 146-163. [CrossRef]

72. Geels, F.W.; Schot, J. Typology of sociotechnical transition pathways. Res. Policy 2007, 36, 399-417. [CrossRef]

73. Geels, F.W. Ontologies, socio-technical transitions (to sustainability), and the multi-level perspective. Res. Policy 2010, 39, 495-510. [CrossRef]

74. Markard, J.; Hekkert, M.; Jacobsson, S. The technological innovation systems framework: Response to six criticisms. Environ. Innov. Soc. Transit. 2015, 16, 76-86. [CrossRef]

75. Schot, J.; Geels, F.W. Strategic niche management and sustainable innovation journeys: Theory, findings, research agenda, and policy. Technol. Anal. Strateg. Manag. 2008, 20, 537-554. [CrossRef]

76. Von Schomberg, R. A Vision of Responsible Research and Innovation. In Responsible Innovation; Owen, R., Bessant, J., Heintz, M., Eds.; John Wiley \& Sons, Ltd.: Chichester, UK, 2013; pp. 51-74. ISBN 978-1-118-55142-4.

77. Schot, J. Constructive Technology Assessment. Available online: https://www.encyclopedia.com/ science/encyclopedias-almanacs-transcripts-and-maps/constructive-technology-assessment (accessed on 28 February 2019).

78. De Hoop, E.; Pols, A.; Romijn, H. Limits to responsible innovation. J. Responsible Innov. 2016, 3, $110-134$. [CrossRef]

79. Akrich, M. The de-scription of technical objects. In Shaping Technology/Building Society: Studies in Sociotechnical Change; Bijker, W.E., Law, J., Eds.; The MIT Press: Cambridge, MA, USA; London, UK, 1992; pp. 205-224.

80. Crettenand, N.; Finger, M. The Alignment between Institutions and Technology in Network Industries. Compet. Regul. Netw. Ind. 2013, 14, 106-129. [CrossRef]

81. Bauwens, T. Socio-Technical Lock-in and the Alignment Framework: The Case of Distributed Generation Technologies. Compet. Regul. Netw. Ind. 2015, 16, 155-181. [CrossRef]

82. Bowman, D.M.; Stokes, E.; Rip, A. (Eds.) Embedding New Technologies into Society: A Regulatory, Ethical and Societal Perspective; Pan Stanford Publishing: Singapore, 2017; ISBN 978-981-4745-74-1.

83. Schot, J.; Rip, A. The past and future of constructive technology assessment. Technol. Forecast. Soc. Chang. 1997, 54, 251-268. [CrossRef] 
84. Unruh, G.C. Escaping carbon lock-in. Energy Policy 2002, 30, 317-325. [CrossRef]

85. Yin, R.K. Case Study Research: Design and Methods, 5th ed.; SAGE: Los Angeles, CA, USA, 2014; ISBN 978-1-4522-4256-9.

86. CTA-Toolbox CTA Toolbox. Available online: https://cta-toolbox.nl/ (accessed on 2 December 2019).

87. DrTen Seasalt Battery. Available online: http://www.drten.nl/zeezout-batterij/?lang=en (accessed on 26 July 2017).

88. Ecovat Ecovat ${ }^{\circledR}$. Available online: http://www.ecovat.eu/?lang=en (accessed on 4 July 2017).

89. Gridflex GridFlex. 2018. Available online: http://gridflex.nl/ (accessed on 8 June 2020).

90. WOW District Heating Co-Operative in East Wageningen. Available online: https://cooperatiewow.nl/ (accessed on 2 December 2019).

91. De Goeijen, G.; Smit, G.; Hurink, J. An Integer Linear Programming Model for an Ecovat Buffer. Energies 2016, 9, 592. [CrossRef]

92. Goeijen, G.; Smit, G.; Hurink, J. Improving an Integer Linear Programming Model of an Ecovat Buffer by Adding Long-Term Planning. Energies 2017, 10, 2039. [CrossRef]

93. De Goeijen, G.J.H.; Hurink, J.L.; Smit, G.J.M. A Heuristic Approach to Control the Ecovat System. In Proceedings of the 2018 IEEE PES Innovative Smart Grid Technologies Conference Europe (ISGT-Europe), Sarajevo, Bosnia-Herzegovina, 21-25 October 2018; pp. 1-6.

94. De Goeijen, G.J.H.; Hoogsteen, G.; Hurink, J.L.; Smit, G.J.M. Using the Ecovat system to supply the heat demand of a neighbourhood. In Proceedings of the 2019 IEEE Milan PowerTech, Milan, Italy, 23-27 June 2019; pp. 1-6.

95. De Groot, A.W. Wall Part, Heat Buffer and Energy Exchange System. U.S. Patent No. 10,024,549, 17 July 2018.

96. De Groot, A.W. Underground Thermal Energy Storage. U.S. Patent Application No. 15/829,854, 29 March 2018.

97. Ephrati, S.; Jonker, H. A Numerical Study of the Ecovat with IFISS. Bachelor's Thesis, University of Twente, Enschede, The Netherlands, 2017.

98. Van den Bosch, R. Modelling the Effects of Different Renovation Scenarios of Apartments on the Configuration of the Ecovat Energy Storage System Finding the Optimal Economic Combination of the Ecovat System and Renovation. Master Thesis, Eindhoven University of Technology, Eindhoven, The Netherlands, 2015.

99. De Goeijen, G. Developing a Method for the Operational Control of an Ecovat System. Ph.D. Thesis, University of Twente, Enschede, The Netherlands, 2019.

100. Quintero Pulido, D.; Hoogsteen, G.; ten Kortenaar, M.; Hurink, J.; Hebner, R.; Smit, G. Characterization of Storage Sizing for an Off-Grid House in the US and the Netherlands. Energies 2018, 11, 265. [CrossRef]

101. Quintero Pulido, D.F.; Ten Kortenaar, M.V.; Hurink, J.L.; Smit, G.J.M. The Role of Off-Grid Houses in the Energy Transition with a Case Study in the Netherlands. Energies 2019, 12, 2033. [CrossRef]

102. Homan, B.; Smit, G.J.M.; van Leeuwen, R.P.; ten Kortenaar, M.V.; Ten, B.V. A comprehensive model for battery State of Charge prediction. In Proceedings of the 2017 IEEE Manchester PowerTech, Manchester, UK, 18-22 June 2017; pp. 1-6.

103. Reijnders, V.; Gerard, M.; Smit, G.; Hurink, J. Testing Grid-Based Electricity Prices and Batteries in a Field Test. In CIRED 2018 Ljubljana Workshop on Microgrids and Local Energy Communities; [0500] (CIRED Workshop Series); CIRED: Ljubljana, Slovenia, 2018.

104. Quintero Pulido, D.F. Energy Storage Technologies for Off-grid Houses. Ph.D. Thesis, University of Twente, Enschede, The Netherlands, 2019.

105. Whittingham, M.S. Materials Challenges Facing Electrical Energy Storage. Mrs Bull. 2008, 33, 411-419. [CrossRef]

106. Liu, J. Addressing the Grand Challenges in Energy Storage. Adv. Funct. Mater. 2013, 23, 924-928. [CrossRef]

107. Koohi-Fayegh, S.; Rosen, M.A. A review of energy storage types, applications and recent developments. J. Energy Storage 2020, 27, 101047. [CrossRef]

108. Jager-Waldau, A.; Lindahl, J.; Heilscher, G.; Kraiczy, M.; Masson, G.; Mather, B.; Mayr, C.; Moneta, D.; Mugnier, D.; Nikoletatos, J.; et al. Electricity produced from photovoltaic systems in apartment buildings and self-consumption: Comparison of the situation in various IEA PVPS countries. In Proceedings of the 2019 IEEE 46th Photovoltaic Specialists Conference (PVSC), Chicago, IL, USA, 16-21 June 2019; pp. 1701-1710.

109. MI Mission Innovation. Available online: http://mission-innovation.net/ (accessed on 13 February 2020). 
110. DeCOOBRAA De COOBRAA: Sustainable Smart Grids Solutions. Available online: http://decoobraa.com/ (accessed on 25 April 2020).

111. B-Corp Certified B Corporation. Available online: https://bcorporation.net/about-b-corps (accessed on 27 May 2020).

112. Van Gastel, E. Ecovat Geeft voor 2,3 Miljoen euro Certificaten van Aandelen uit via NPEX-Effectenbeurs, Smart Storage Magazine. Available online: https://smartstoragemagazine.nl/nieuws/i18306/ecovat-geeftvoor-2-3-miljoen-euro-certificaten-van-aandelen-uit-via-npex-effectenbeurs (accessed on 25 April 2020).

113. Warnaars, J.; Kooiman, A.; den Ouden, B. System Consequences of Ecovat: Quantification of Avoided Costs for Grid Reinforcement and Peak Power Plants; Berenschot: Utrecht, The Netherlands, 2018; p. 15.

114. Rijksoverheid 120 Miljoen Euro Voor 'Proeftuinen' Aardgasvrije Wijken in 27 Gemeenten. Available online: https:/www.rijksoverheid.nl/actueel/nieuws/2018/10/01/120-miljoen-euro-voor$\backslash \mathrm{T} 1 \backslash$ textquoteleftproeftuinen\T1\textquoteright-aardgasvrije-wijken-in-27-gemeenten (accessed on 25 April 2020).

115. INTERREG INTERREG Germany Netherlands. Available online: https://www.deutschland-nederland.eu/en/ (accessed on 12 February 2020).

116. EnergystorageNL. Available online: https://www.energystoragenl.nl/ (accessed on 13 February 2020).

117. Van der Ploeg, H. Arnhemse Wijk Heijenoord in Actie Tegen Vrachtverkeer Voor Aanleg 'Ecovat'; de Gelderlander: Arnehm, The Netherlands, 2019.

118. Meulenkamp, E.; van Bree, T.; Geurts, A. Verkenning Batterijen 2: Positie NL in de Waardeketen; TNO: The Hague, The Netherlands, 2019.

(C) 2020 by the authors. Licensee MDPI, Basel, Switzerland. This article is an open access article distributed under the terms and conditions of the Creative Commons Attribution (CC BY) license (http://creativecommons.org/licenses/by/4.0/). 